\title{
La mise au propre en architecture. Toilette et salle de bains en France au tournant du siècle
} (1880-1914)

\section{Monique Eleb}

\section{(2) OpenEdition}

\section{Journals}

Édition électronique

URL : https://journals.openedition.org/tc/782

DOI : $10.4000 /$ tc. 782

ISSN : 1952-420X

Éditeur

Éditions de l'EHESS

\section{Édition imprimée}

Date de publication : 1 février 1990

ISSN : 0248-6016

\section{Référence électronique}

Monique Eleb, « La mise au propre en architecture. Toilette et salle de bains en France au tournant du siècle (1880-1914) », Techniques \& Culture [En ligne], 13| 1990, mis en ligne le 16 janvier 2006, consulté le 29 septembre 2022. URL : http://journals.openedition.org/tc/782 ; DOI : https://doi.org/10.4000/tc. 782

Ce document a été généré automatiquement le 29 septembre 2022.

Tous droits réservés 
La mise au propre en architecture. Toilette et salle de bains en France au tournant du siècle (1880-1914)

Monique Eleb 